MIDPI

sciforum
MOL2NET, International Conference Series on Multidisciplinary Sciences

06. MODECO-05: Molec. Diversity \& Ecosystems, Puyo, Ecuador-Porto, Portugal-Paris,

\title{
Optimization of the use of residuals in pig farms: A mini- bibliographic review
}

\author{
Willan Caicedo $^{1,2}$, Keyla Apunte ${ }^{1}$, Lesly Cayancela ${ }^{1}$, Santiago Aguiar ${ }^{l}$
}

${ }^{a}$ Facultad de Ciencias de la Tierra, Universidad Estatal Amazónica, Puyo, Pastaza, Ecuador

${ }^{b}$ Granja Agropecuaria Caicedo, Puyo, Pastaza, Ecuador

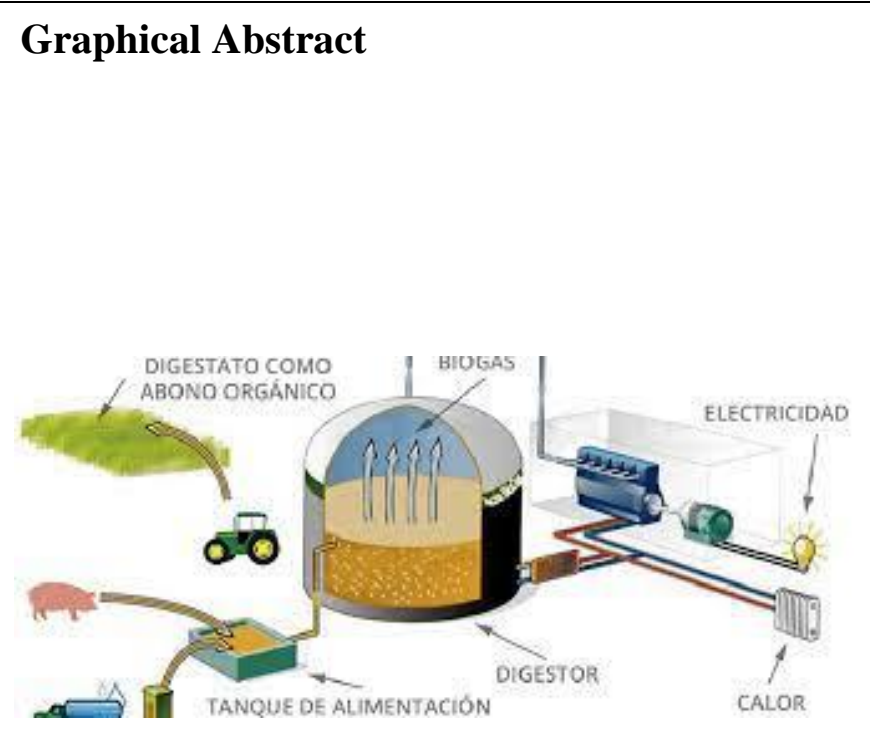

Source: (Soluciones Integrales de Combustión, 2021)

\section{Abstract}

The excreta and urine of the pigs, by not being treated in the farms, constitute the main cause of toxicity of the soil, air and water, generating later problems in livestock and agricultural productions, affecting small and medium producers, affecting public health, decreasing the quality of life and generating environmental damage that must be remedied with a high economic investment. The objective of this bibliographic review was to evaluate the transformation and use of pig waste (manure and urine) in agricultural production. At the international level there are multiple uses for the processing of these residuals, among which the following stand out; the production of bioles and compost as a source of nutrients for crops, and the production of biogas and electrical energy that serve as ecological energy for cooking, lighting and heating the piglets. The success of taking advantage of the waste generated by a pig production system has a great impact on the generation of fertilizers and energy for use in integrated agricultural production systems.

Key words: Pig waste, bio-fertilizers, methane, electricity, swine excreta. 


\section{Introduction}

The scarce handling and use of excreta, urine and residual water that are generated every day in the different stages of pig production, has become a weakness in pig farming, since it contributes to environmental contamination. On the other hand, the treatment of these residuals generates environmental and economic benefits through the production of biogas, electricity and bio-fertilizers for agricultural production.

At the global level, the agricultural vision has been redirected to the importance of environmentally friendly practices. According to the Food and Agriculture Organization of the United Nations FAO (2014), it is possible when animal production is part of sustainable systems where agriculture benefits from the waste obtained from the system.

According to Beyli (2015), excreta contain significant amounts of lipids, sulfur compounds, amino acids, carbohydrates, proteins, urea, nitrogen $(\mathrm{N})$, phosphorus $(\mathrm{P})$, potassium $(\mathrm{K})$, calcium $(\mathrm{Ca})$, magnesium $(\mathrm{Mg})$ and sodium $(\mathrm{Na})$. It also contains micronutrients such as iron $(\mathrm{Fe})$, zinc $(\mathrm{Zn})$, copper $(\mathrm{Cu})$ and manganese $(\mathrm{Mn})$, as well as harmful elements such as cadmium $(\mathrm{Cd})$, lead $(\mathrm{Pb})$, arsenic (As) or mercury $(\mathrm{Hg})$, thus emanating high densities of ammonia and greenhouse gases which are produced by different microorganisms through metabolic processes.

The inadequate handling of excreta is a factor that negatively affects pig production systems, taking into account the pollutants emitted throughout their productive cycle due to the scant handling that they are given, which is why the They must be worked to turn them into strengths for the benefit of the production system (Ninabanda, 2012).

In a pig farm, the degree of contamination will be determined according to the feeding and the physiological state of the animal, having an effect on the physical-chemical structure of the manure, as mentioned by Paiva (2016), revealing that the residual water is a stream of highly polluting fluid for which it needs to be treated with oxidation lagoons, where all the wastewater from all the productive stages of a farm is concentrated. The objective of this bibliographic review was to evaluate the transformation and use of pig waste (manure and urine) in agricultural production.

\section{Materials and Methods}

The research was based on the use of the exploratory and documentary method, a systematic search was carried out on the use of pig residuals in databases of international prestige.

\section{Results and Discussion}

\section{Biogas Production}

Biogas is a combination of different gases, which arise from the anaerobic decomposition of organic matter such as: pig waste and organic waste, these are used by biodigesters. The largest component is methane $\left(\mathrm{CH}_{4}\right)$, a greenhouse gas like carbon dioxide $\left(\mathrm{CO}_{2}\right)$. Biogas also contains hydrogen $(\mathrm{H})$, nitrogen $(\mathrm{N})$, carbon monoxide $(\mathrm{CM})$, oxygen $(\mathrm{O})$ and hydrogen sulfide $\left(\mathrm{H}_{2} \mathrm{~S}\right)$, this composition will vary depending on the substrate to be degraded (Cepero et al., 2012). For the use of biogas, some of its components must be removed, including $\mathrm{H}_{2} \mathrm{~S}$, due to its level of corrosivity when used in energy conversion machinery, moisture must also be eliminated since it directly influences the burning process. In the same way, for vehicular use and the distribution of natural gas, $\mathrm{CO}_{2}$ and other impurities must be 
separated, in such a way that the biogas has a high percentage of methane (> 95\%) (Garcilasso et al., 2018). Biogas is an important product capable of providing sustainable energy to agricultural farms through the use of biodigesters from the use of raw materials reducing environmental pollution that has greatly affected due to its high content of greenhouse gases (Venegas et al., 2018).

\section{Electric power}

Nowadays, the amount of investments to search for new energy alternatives is high, having two essential factors: low cost and clean. Pig production generates a considerable amount of waste that is transformed and used in various ways, such is the case of electrical energy that is being implemented in several countries (Sousa et al., 2020).

Latin America, for example, Mexico's objective is the production of decentralized electricity, thus having the dissemination of electricity generation sources throughout its geography, with pig production being the ones that provide an opportunity for development to the current electricity system. To obtain electrical energy, it is necessary to transform chemical energy into calorific energy from the resulting amount of biogas, the machine to be used for this conversion must be taken into account due to its low efficiency, there are two economic alternatives, the first being the use of gas internal combustion engines with its proper coupling to an electric generator, on the other hand, if you have a large-scale biogas production, a gas turbine is used. It is estimated that for every $\mathrm{m}^{3}$ of biogas production $1.67 \mathrm{kWh}$ of electricity is obtained in tropical conditions but because Ecuador is a country that has three regions with different conditions, altitude and temperature, the amount of $\mathrm{kWh}$ to be obtained will vary that needs a corrective formulation (Martínez, 2015).

\section{Production of bio-fertilizers}

The composition of animal and vegetable organic matter is known as bio-fertilizer, we can find liquid bio-fertilizers such as biol and solid texture such as bristle, bocashi and compost from all this the soil benefits who receives the essential nutrients stored in the bio-fertilizer, the plants They receive the growth-promoting substances found in this organic fertilizer, generating better productivity and enhancing agricultural activity (Grageda et al., 2012).

\section{Biol}

A part of the anaerobic fermentation produces a liquid fraction called biol that is generated in the biodigester, the nutrients that we can find are nitrogen, phosphorus, potassium. In agricultural production in the agricultural axis, some amendments must be made within the crops to provide vigor in roots and fruits that is why the biol is used because it is known to have anaerobic bacteria that discard plant hormones causing a great advantage in agriculture being able to compete with chemical fertilizers by helping to have a soil free of toxic residues (Shirakawa, 2016). Many of the farmers are unaware of the benefit that pig residues can provide to their crops, so it is important to know about efficient and environmentally friendly alternatives that benefit productions, that is why knowledge of the process is essential for a better management in agricultural and livestock systems. 


\section{Bocashi}

Its origin dates back to Japanese agriculture, which has been used as organic fertilizer, which is decomposed in a process with the presence of oxygen, using plant and / or animal waste as raw material of the locality. In the soil, it activates and raises the dose of microorganisms, improving physical characteristics, during its preparation no toxic gases or bad odors are formed due to the control in each stage of the fermentation process, thus avoiding putrefaction. For its preparation there is no rule to follow, each individual does it depending on the elements at their disposal, for example, to obtain 1000 $\mathrm{kg}$ of bocashi $115 \mathrm{~kg}$ of pig manure is required, it is a source of nutritional elements such as calcium , potassium, phosphorus, nitrogen's and micronutrients, ash also contains potassium in high quantities, to neutralize the acidity of manure and vegetable residues lime is needed in the same way molasses acts as a source of energy, to suppress pathogenic microorganisms it is necessary A derivative of milk, the hormones and enzymes that promote cell division and root growth are produced by yeasts and last but not least water (Ramos et al., 2014).

\section{Cerdaza}

It is that food that is not assimilated by the digestive system of the pig, enriching it with its intestinal microbiota, which makes it a good quality material to be used in the agricultural field as biofertilizer, helping to reduce the strong impact caused by its use. of chemical fertilizers in cultivation soils. The area of solid pig waste will allow the easy collection of bristle in an estimated time of 25 days to dry it later and be able to market it as fertilizer for crops or for animal feed (Galero and Richard, 2016).

\section{Compost}

It is used as organic fertilizer allowing to improve production, and avoiding an independence from external inputs that have a high economic cost, high rates of sustainable agriculture, reduction of the use of agrochemicals, which is beneficial for the environment and for the harvested products. A very important alternative for those who cannot afford such expenses, obtain by using compost a clean and friendly technology with their environment (Cruz et al., 2019).

It should be taken into account that composting has several substrates, one of which is the deep bed that is widely used to produce compost. To avoid leachate in the decomposition process it is recommended to pave the base of the compost. For the formation of a compost pile, the space available must be taken into account, taking as a guideline that the height will be half of its base, this space must be filled with different layers. It must be taken into account that a source rich in nitrogen is necessary and in the same way a source rich in carbon is so that the mixture of these two, plus water and oxygen, in terms of quantity is estimated that $73 \mathrm{~kg}$ of carbon source and a $24.9 \mathrm{~kg}$ of a nitrogen source, giving a compost row of $97.9 \mathrm{~kg}$ (Barbaro et al., 2019).

The layers will depend on the type of material and the objective of the composting, an approximate value of $20 \mathrm{~cm}$ in height, which should have the characteristic of draining leachates, such as sugar cane stalks, opting for a second layer of organic crop residues, followed by the third layer of animal excreta, in this case pig residues, it is important to dry hay, or crop residues. It is necessary that after each stage 
it is watered with abundant water since the humidity factor is very important for proper fermentation, finally nylon or blankets are placed to protect from external factors Turning is an activity that must be carried out in a pot that each layer from the beginning to the end and vice versa, in addition to aerating the material (Almaguel et al., 2015).

\section{Conclusions}

The success of taking advantage of the waste generated by a pig production system has a great impact on the generation of fertilizers and energy for use in integrated agricultural production systems.

\section{References}

$>$ Almaguel, R. E., Cruz, Ly. \& J. (2015). El compostaje. Una tecnología sostenible para la familia en el tratamiento de las excretas porcinas y los residuos orgánicos de la granja. Instituto de Investigaciones Porcinas, 82-86

$>$ Barbaro, L., Karlanian, M., Rizzo, \& Riera, N. (2019). Characterization of different compost for use as component of substrates. Chilean Journal of Agricultural and Animal Sciences, 35(2): 2636

$>$ Beily, M. (2015). Caracterización de efluentes de cerdos, con énfasis en su biodegradabilidad anaeróbica. Instituto tecnológico de Buenos Aires, Argentina.

$>$ Cruz, E., Amaguel, R. \& Reyes, Z. (2019). Caracterización físico-química y microbiológica del lixiviado generado del compostaje de excreta porcina para su uso como bono Orgánico. IEEE Transactions on Software Engineering, 26(4): 33-44

$>$ FAO. (2014). Producción y Sanidad animal. Available in: http://www.fao.org/ag/againfo/themes/es/pigs/Environment.html?fbclid=IwAR14wry9J2zascp Qhx2H7RNoqij572OJqRAEVwAv3qGRXQ5TrAhFdOj31WY

> Galero, N. \& Richard, K. (2016). Estudio de pre-factibilidad para el establecimiento de una granja porcino semi-tecnificada en la Comarca Wanwas, Municipio de Rio Blanco, Matagalpa. Universidad Nacional Agraria.

$>$ Garcilasso, V., Djalma, J., Dos Santos, M. \& Caio, L. (2018). Tecnologias de produção e uso de biogás e biometano: Part. I Biogás; Part. II Biometano. São Paulo: IEE-USP, Brasil, 218 p.

$>$ Grageda, O., Díaz, F., Peña, J. \& Vera, J. (2012). Impacto de los biofertilizantes en la agricultura. Revista Mexicana de Ciencias Agrícolas, 3(6): 261-74

$>$ Martínez, M. (2015). Producción potencial de biogás empleando excretas de ganado porcino en el Estado de Guanajuato. Nova Scientia, 7(15): 96. doi: 10.21640/ns.v7i15.273

$>$ Ninabanda, J. (2012). Alternativas de manejo de las excretas porcinas. Escuela Superior Politécnica de Chimborazo, Riobamba, Ecuador.

$>$ Paiva, F. (2016). Propuesta de aprovechamiento del biogás obtenido a partir del tratamiento de las aguas residuales generadas en la empresa rico cerdo F\&G S.A.C. para su uso como biocombustible en los sistemas de calefacción de las áreas de maternidad. Universidad Santo Toribio de Mogrovejo.

$>$ Ramos, D., Elein, A., Soto, F. \& Cabrera, J. (2014). Bocashi: abono orgánico elaborado a partir de residuos de la producción de plátanos en bocas del toro, Panamá. Instituto Nacional de Ciencias Agrícolas, 25(2): 90-97 
Shirakawa, A. (2016). Evaluación del método de ensilado de excretas de cerdo en la generación de biogás y biol mediante biodigestores. Universidad Nacional Agraria La Molina, Lima, Perú.

$>$ Soluciones Integrales de Combustión. (2021). Biogás, ¿energía renovable de futuro? Alternativa al gas natural. Available: https://solucionesdecombustion.com/biogas-energia-renovable-defuturo/

Sousa, I., André P., Borges, A. \& Dos Santos, N. (2020). Energy Potential of Biogas from Pig Farms in the State of Minas Gerais, Brazil. Engenharia Agrícola, 4430: 96-404

$>$ Venegas, J., Deb Raj Aryal. \& Pinto, R. (2018). Biogás, la energía renovable para el desarrollo de granjas porcícolas en el Estado de Chiapas. Análisis Económico, 34(85): 169-87 